\title{
ANTI-INFLAMMATORY ACTIVITY OF AQUEOUS EXTRACTS OF GRACILARIA
}

\author{
CHALINI K., JOHNSON M. ', ADAIKALARAJ G., VIDYARANI GEORGE, RAMAKRISHNAN P.
}

Centre for Plant Biotechnology, Research Department of Botany, St. Xavier's College (Autonomous), Palayamkottai, Tamil Nadu, India 627002

Email: ptcjohnson@gmail.com

Received: 20 May 2017, Revised and Accepted: 22 Jul 2017

\begin{abstract}
Objective: In the present investigation an attempt was made to examine the anti-inflammatory potential of aqueous extracts of Gracilaria salicornia C. Ag., Gracilaria edulis (Gmelin) Silva, Gracilaria corticata J. Ag., Gracilaria fergusonii J. Ag.,and Gracilaria verrucosa (Hudson) Papenfus from Mandapam, Gracilaria edulis (Gmelin) Silva., Gracilaria verrucosa (Hudson) Papenfus from Pulicate Lake, Gracilaria fergusonii J. Ag., Gracilaria corticata J. Ag. and Gracilaria corticata J. Ag. var. cylindrica from Tuticorin using heat induced haemolysis of RBC. In addition, the present study is focused to reveal the locality specific anti-inflammatory activities of selected Gracillaria species.
\end{abstract}

Methods: The fresh seaweeds were boiled with distilled water (1:20 W/V) for $2 \mathrm{~h}$. The slurry was filtered through Whatman No. 41 filter paper and condensed. The semi-solid crude extracts were used for anti-inflammatory analysis.

Results: An aqueous extracts of studied Gracilaria species were effective in inhibiting the heat induced haemolysis at different concentrations. The results showed the dose dependent protection. The percentage of anti-inflammatory activity of studied Gracillaria was varied from 43.81 to 95.55 . The highest percentage (95.55\%) of activity was observed in $250 \mu \mathrm{g} / \mathrm{ml}$ of $G$. edulis aqueous extracts. The anti-inflammatory activity of studied Gracillaria species at $250 \mu \mathrm{g} / \mathrm{ml}$ were as follows G. edulis (Mandabam) $>$ G. corticata (Mandabam) $>$ G. verucosa (Mandabam) $>$ G. salicornia (Mandabam) $>$ G. ferugosonii (Tuticorin) $>$ G. ferugosonii $($ Mandabam) $>$ G. edulis (Pulicate) $>$ G. corticata (Tuticorin) $>$ G. verucosa (Pulicate) $>$ G. corticata var. cylindrica (Tuticorin).

Conclusion: The results of the present study clearly explained the anti-inflammatory potential of the studied Gracillaria species. The aqueous 0extracts of Gracillaria collected from Mandapam showed the highest percentage of protection activity. This study results confirm the existence of active principle responsible for the anti-inflammatory activity. Further studies are required to isolate the active principles without any side effects.

Keywords: Gracillaria, Seaweeds, Anti-inflammatory

(c) 2017 The Authors. Published by Innovare Academic Sciences Pvt Ltd. This is an open access article under the CC BY license (http://creativecommons.org/licenses/by/4.0/) DOI: http://dx.doi.org/10.22159/ijcpr.2017v9i5.22130

\section{INTRODUCTION}

Due to the presence of a rich source of biologically active metabolites the seaweeds are a valuable pharmaceutical potential candidate for the drug development. The seaweed derived metabolites possess various biological activities especially with antiinflammatory activities [1, 2]. Previous research on seaweeds polysaccharides revealed the anti-inflammatory properties and employed as an alternate candidate with anti-inflammatory $[3,4]$. Several species of marine seaweeds are reported with antiinflammatory activities viz., Gracilaria textorii and Gracilaria verrucosa [5, 6], Caulerpa [7], Caulerpa racemosa, Cystoseira crinita [8], Sargassum swartzii and Ulva reticulata [9], Dichotomaria obtusata [10], Gracilaria cornea [11], P. tetrastomatica and P. gymnospora [12], Dictyota menstrualis [13], Padina tertastomatica, Sargassum wightii, Gracilaria edulis and Caulerpa racemosa [14], Spatoglossum schroederi [15], Cladophora indica [16], Gracillaria edulis [17], Undaria Pinnatifida, Laminaria Japonica, Sargassum fulvellum and Hizikia fusiforme [18] and Lobophora variegata [19]. Only very few studies were reported from the coast of Tamil nadu $[14,17,19,20]$. But there is no report on the anti-inflammatory activities of fresh aqueous extracts of Gracillaria species from Tamil Nadu. In the present investigation an attempt was made to examine the anti-inflammatory potential of aqueous extracts of Gracilaria salicornia C. Ag., Gracilaria edulis (Gmelin) Silva, Gracilaria corticata J. Ag., Gracilaria fergusonii J. Ag.,and Gracilaria verrucosa (Hudson) Papenfus from Mandapam, Gracilaria edulis (Gmelin) Silva., Gracilaria verrucosa (Hudson) Papenfus from Pulicate Lake, Gracilaria fergusonii J. Ag., Gracilaria corticata J. Ag. and Gracilaria corticata J. Ag. var. cylindrica from Tuticorin using heat induced haemolysis of RBC. In addition, the present study is focused to reveal the locality specific anti-inflammatory activities of selected Gracillaria species.

\section{MATERIALS AND METHODS}

\section{Plant material}

The Gracilaria salicornia C. Ag., Gracilaria edulis (Gmelin) Silva, Gracilaria corticata J. Ag., Gracilaria fergusonii J. Ag.,and Gracilaria verrucosa (Hudson) Papenfus were collected from Mandapam coast, Gracilaria edulis (Gmelin) Silva., Gracilaria verrucosa (Hudson) Papenfus from Pulicate Lake, Gracilaria fergusonii J. Ag., Gracilaria corticata J. Ag. and Gracilaria corticata J. Ag. var. cylindrica from Tuticorin, India. Further the species are identified using Phycologia Indica by Srinivasan [21]. The fresh seaweeds were used for extraction. The fresh seaweeds were boiled with distilled water $(1: 20 \mathrm{~W} / \mathrm{V})$ for $2 \mathrm{~h}$. The slurry was filtered through Whatman No. 41 filter paper and condensed. The semi-solid crude extracts were used for anti-inflammatory analysis. For anti-inflammatory analysis, 10 mg crude extracts were dissolved in $10 \mathrm{ml}$ of distilled water $(\mathrm{W} / \mathrm{V})$. From this, the aliquots 50,100, 200 and $250 \mu \mathrm{g} / \mathrm{ml}$ were prepared.

\section{Membrane stabilization}

\section{Preparation of red blood cells (RBCs) suspension}

The Blood was collected from a healthy human volunteer who has not taken any NSAIDs (Non-Steroidal Anti-Inflammatory Drugs) for $2 \mathrm{w}$ prior to the experiment and transferred to the centrifuge tubes. The tubes were centrifuged at $3000 \mathrm{rpm}$ for $10 \mathrm{~min}$ and were washed three times with equal volume of normal saline. The volume of blood was measured and re constituted as $10 \% \mathrm{v} / \mathrm{v}$ suspension with normal saline [22, 23].

\section{Heat induced haemolysis [22, 24]}

The reaction mixture $(2 \mathrm{ml})$ includes $1 \mathrm{ml}$ of different concentrations of selected Gracilaria species aqueous extracts (50, 100, 200 and 250 
$\mu \mathrm{g} / \mathrm{ml}$ ) and $1 \mathrm{ml}$ of $10 \%$ RBCs suspension, instead of test sample the only saline was added to the control test tube. Aspirin was employed as a positive control. The reaction mixtures were incubated in water bath at $56^{\circ} \mathrm{C}$ for $30 \mathrm{~min}$. At the end of the incubation, the tubes were cooled under running tap water. The reaction mixtures were centrifuged at $3000 \mathrm{rpm}$ for $5 \mathrm{~min}$ and the absorbance of the supernatants was measured at $560 \mathrm{~nm}$. The experiment was performed in triplicates for all the test samples.

The Percentage inhibition of Haemolysis was calculated as follows:

Percentage inhibition $=($ Abs control-Abs sample $) /$ Abs control X 100

Statistical analysis was performed using SPSS 21 software. Analysis of variance and pair wise Pearson correlation test was performed. The $\mathrm{p}<0.05$ was considered significant.

\section{RESULTS}

Aqueous extracts of studied Gracilaria species were effective in inhibiting the heat induced haemolysis at different concentrations. The results showed the dose dependent protection (table 1). The percentage of anti-inflammatory activity of studied Gracillaria was varied from 43.81 to 95.55 (table 1). The highest percentage (95.55\%) of activity was observed in $250 \mu \mathrm{g} / \mathrm{ml}$ of $G$. edulis aqueous extracts. The anti-inflammatory activity of studied Gracillaria species at 250 $\mu \mathrm{g} / \mathrm{ml}$ were as follows (table 1) G. edulis (Mandabam) $>G$. corticata (Mandabam) $>G$. verucosa $($ Mandabam $)>G$. salicornia (Mandabam) $>G$. ferugosonii (Tuticorin) $>G$. ferugosonii (Mandabam) $>G$. edulis (Pulicate) $>$ G. corticata (Tuticorin) $>$ G. verucosa (Pulicate) $>$ G. corticata var. cylindrica (Tuticorin) (table 1). The anti-inflammatory/protection activity of the aqueous extracts of studied Gracillaria species was significant at $\mathrm{p}<0.005$. Among the three localities studied, the Gracillaria species collected from Mandabam showed more activity than other two studied localities. This may be due to soil nutritional composition and ecological conditions of the coast. A Pearson moment-correlation was run to determine the relationship between the individual concentrations and their protection ability. There was a strong positive correlation between the concentration and protection ability, which was statistically significant at $p<0.05$ level (2-tailed) (table 1). The correlation results clearly explained the dose dependent protection of the studied Gracillaria species.

Table 1: Anti-inflammatory activity of Gracillaria species

\begin{tabular}{|c|c|c|c|c|c|c|}
\hline \multirow{2}{*}{$\begin{array}{l}\text { Species/ } \\
\text { concentration }\end{array}$} & \multirow[t]{2}{*}{ Locality } & \multicolumn{4}{|c|}{$\%$ of protection } & \multirow[t]{2}{*}{ Pearson correlation ( $\mathrm{r}$ ) } \\
\hline & & 50 & 100 & 200 & 250 & \\
\hline G. fergusonii. & Tuticorin & $63.98^{*}$ & $66.62^{*}$ & $70.10^{*}$ & 79.97 & 0.912 \\
\hline G. corticata & & 43.81 & 52.71 & $64.39^{*}$ & $71.07^{*}$ & 0.849 \\
\hline $\begin{array}{l}\text { G. corticata } \\
\text { var. cylindrica }\end{array}$ & & 57.16 & $58.83^{*}$ & $66.34^{*}$ & $67.87^{*}$ & 0.862 \\
\hline G. edulis & Pulicate Lake & 45.06 & $59.94^{*}$ & $69.68^{*}$ & 74.55 & 0.968 \\
\hline G. verrucosa & & 47.15 & 57.44 & $59.53^{*}$ & $68.15^{*}$ & 0.974 \\
\hline G. salicornia & Mandabam & 52.57 & $73.99^{*}$ & 79.97 & 82.75 & 0.975 \\
\hline G. edulis & & 81.50 & 82.20 & 83.59 & 95.55 & 0.974 \\
\hline G. corticata & & $68.85^{*}$ & 86.65 & 89.85 & 90.54 & 0.949 \\
\hline G. fergusonii & & 56.61 & 61.47 & $74.83^{*}$ & $77.47^{*}$ & 0.995 \\
\hline G. verrucosa & & $69.82 *$ & 78.58* & 80.39 & 87.90 & 0.958 \\
\hline
\end{tabular}

*indicates the mean differences are significant at $\mathrm{P}<0.05$ level.

\section{DISCUSSION}

In the present study, RBC membrane stabilization of method was used to determine the anti-inflammatory properties of Gracillaria species. Similar to that Dependra and Bisu [25] also employed the RBC membrane stabilization of method to determine the anti-inflammatory property. The varied frequency ( 43.81 to $95.55 \%$ ) of protection/activity depends on the phytochemical composition of the aqueous extracts of the studied Gracillaria species. The occurrence of flavonoids was observed in G. salicornia and G. corticata [26]. Krishnaveni and Johnson [27] reported the existence of alkaloids, saponins, steroids and tannins in the aqueous extracts of $G$. corticata. Flavonoids and triterpenoids occurrence was reported in G. edulis [28]. The existence of these metabolites may be responsible for the activity. Vijayalakshmi [17] observed more frequency $58.2 \%$ of anti-inflammatory activity in the aqueous extracts of $G$. edulis. The results of the present study also supplemented and coincided with Vijayalakshmi observations. But in the present study, G. edulis aqueous extracts showed $95.55 \%$ of activity. The results of the present study clearly explained the anti-inflammatory potential of the studied Gracillaria species. The aqueous extracts of Gracillaria collected from Mandapam showed the highest percentage of protection activity. This study results confirm the existence of active principle responsible for the anti-inflammatory activity. Further studies are required to isolate the active principles without any side effects. The result is identified an alternate source for the isolation of anti-inflammatory agent.

\section{CONFLICT OF INTERESTS}

\section{Declare none}

\section{REFERENCES}

1. Smith AJ. Medicinal and pharmaceutical uses of seaweed natural products: a review. J Appl Phycol 2004;16:245-62.
2. Serhan CN. Novel w-3-derived local mediators in antiinflammation and resolution. Pharmacol Ther 2005;105:7-21.

3. Ravikumar S, Anburajan L, Ramanathan G, Kaliaperumal N. Screening of seaweed extracts against antibiotic resistant post operative infectious pathogen. Seaweed Res Utiln 2002;24:95-9.

4. Sureshkumar S, John JAC, Ravikumar S. Antimicrobial activity of acetone extracts of seaweeds against human pathogens. Seaweed Res Utiln 2002;24:111-5.

5. Okada Y, Miyauch N, Suzuki K, Kobayashi T, Tsutsui C, Mayuzumi K, et al. Search for naturally occurring substances for prevention against the complications of diabetes; inhibitory effect on aldose reductase and platelet aggregation. Nat Med 1994;48:324-9.

6. Yoshizawa Y, Tsunehiro J, Nomura K, Itoh M, Fukui F, Ametani A, et al. In vivo macrophage-stimulation activity of the enzymedegraded water-soluble polysaccharide fraction from a marine alga (Gracilaria verrucosa). Biosci Biotechnol Biochem 1996;60:1667-71.

7. De Souza ET, De Lira DP, De Queiroz AC, Da Silva DJC, De Aquino $\mathrm{AB}$, Mella EAC, et al. The antinociceptive and anti-inflammatory activities of caulerpin, a bisindole alkaloid isolated from seaweeds of the genus Caulerpa. Mar Drugs 2009;7:689-704.

8. Mhadhebi L, Laroche-Clary A, Robert J, Bouraoui AR. Antiinflammatory, antiproliferative and antioxidant activities of organic extracts from the Mediterranean seaweed, Cystoseira crinita. Afr J Biotechnol 2011;10:16682-90.

9. Hong DD, Hien HM, Anh HTL. Studies on the analgesic and antiinflammatory activities of Sargassum swartzii (Turner) C. Agardh (Phaeophyta) and Ulva reticulata Forsskal (Chlorophyta) in experiment animal models. Afr J Biotechnol 2011;10:2308-14.

10. Vazquez AIF, Sanchez CMD, Delgado NG, Alfonso AMS, Ortega YS, Sanchez HC. Anti-inflammatory and analgesic activities of red seaweed Dichotomaria obtusata. Brazilian J Pharm Sci 2011;47:111-8. 
11. Coura CO, de Araffljo IWF, Vanderlei EOS, Rodrigues JAG, Ana LGQ Fontes BP, et al. Antinociceptive and anti-inflammatory activities of sulphated polysaccharides from the red seaweed Gracilaria cornea. Basic Clin Pharmacol Toxicol 2012;110:335-41.

12. Praveen NK, Kajal C. Antioxidant and anti-inflammatory potential of the aqueous extract and polysaccharide fraction from brown marine macro algae Padina sp. from the gulf of mannar of peninsular. India J Coastal Life Med 2013;1:39-49.

13. Albuquerque IRL, Cordeiro SL, Gomes DL, Dreyfuss JL, Alves Filgueira LG, Edda LL, et al. Evaluation of antinociceptive and anti-inflammatory activities of a hetero-fucan from Dictyota menstrualis. Mar Drugs 2013;11:2722-40.

14. Radhika D, Veerabahu C, Priya R. Anti-inflammatory activities of some seaweed collected from the gulf of mannar coast, Tuticorin, South India. Int J Pharm Biol Sci 2013;4:39-44.

15. Junior SQ Carneiro VHA, Fontenelle TPC, Chaves LDS, Mesquita JX, de Brito TV, et al. Antioxidant and anti-inflammatory activities of methanol extract and its fractions from the brown seaweed Spatoglossum schroederi. J Appl Phycol 2015;27:2367-76.

16. Neelam Begum, Rao DS. A preliminary study on the antiinflammatory activity of marine green macro algae using wistar rats. Int J Pharm Sci Rev Res 2015;34:241-4.

17. Vijayalakshmi S. Screening and anti-inflammatory activity of methanolic and aqueous extracts of seaweed Gracillaria edulis. Int J Modern Chem Appl Sci 2015:2:248-50.

18. $\mathrm{Oh} \mathrm{JH}$, Kim J, Lee Y. Anti-inflammatory and anti-diabetic effects of brown seaweeds in high-fat diet-induced obese mice. Nutr Res Practice 2016;10:42-8.

19. Thennarasan S, Murugesan S, Chidambaranathan $\mathrm{N}$ Sivamurugan V. Analgesic, anti-inflammatory and antipyretic activity of the methanol extracts of brown alga Lobophora variegate (J. V. Lamouroux) Womersley ex E. C. Oliveir. Am J Phytomed Clin Ther 2016;4:42-57.
20. Ananthi S, Gayathri V, Chandronitha C, Lakshmisundaram R, Vasanthi HR. Free radical scavenging and anti-inflammatory potential of a marine brown alga Turbinaria ornate (Turner) J Agardh. Indian J Geo-Marine Sci 2011;40:664-70.

21. Srinivasan KS. Phycologia Indica Botanical Survey of India, India; 1973.

22. Sakat $\mathrm{S}$, Juvekar $\mathrm{AR}$, Gambhire $\mathrm{MN}$. In vitro antioxidant and anti-inflammatory activity of methanol extract of Oxalis corniculata Linn. Int J Pharma Pharmacol Sci 2010;2:146-55.

23. Sadique J, Al-Rqobahs WA, EIGindi ABR. The bioactivity of certain medicinal plants on the stabilization of RBS membrane system. Fitoterapia 1989;60:525-32.

24. Shinde UA, Kulkarni KR, Phadke AS, Nair AM, Dikshit V, Mungantiwar J, et al. Mast cell stabilizing and lipoxygenase inhibitory activity of Cedrus deodara (Roxb.) Loud. Wood Oil. Indian J Exp Biol 1999;37:258-61.

25. Dependra C, Bisu S. Study of in vitro anti-inflammatory activity of ethnomedicinal plants of sikkim Viscum articulatum and Acorus calamus. Asian J Pharm Clin Res 2016;9:119-22.

26. Alireza G, Leila S, Afsaneh Y. Cytotoxic, antioxidant and phytochemical analysis of Gracilaria species from the Persian Gulf. Adv Biomed Res 2016;5:139.

27. Krishnaveni E, Johnson M. Preliminary phytochemical, UV-VIS, HPLC and antibacterial studies on Gracilaria corticata. Asian Pacific J Trop Biomed; 2012. p. S568-S574.

28. Abirami RG, Kowsalya S. Phytochemical screening, microbial load and antimicrobial activity of underexploited seaweeds. Int Res J Microbiol 2012;3:328-32.

\section{How to cite this article}

- Chalini K, Johnson M, Adaikalaraj G, Vidyarani George, Ramakrishnan P. Anti-inflammatory activity of aqueous extracts of Gracilaria. Int J Curr Pharm Res 2017;9(5):17-19. 